University of Arkansas, Fayetteville

ScholarWorks@UARK

Does Choice Matter for School Choice? An Instrumental Variables Analysis of the Effect of Choice on Parental Satisfaction in Charter Schools

Corey A. DeAngelis

University of Arkansas, Fayetteville, cadeange@uark.edu

Follow this and additional works at: https://scholarworks.uark.edu/edrepub

Part of the Educational Assessment, Evaluation, and Research Commons, Educational Leadership Commons, and the Other Educational Administration and Supervision Commons

\title{
Citation
}

DeAngelis, C. A. (2017). Does Choice Matter for School Choice? An Instrumental Variables Analysis of the Effect of Choice on Parental Satisfaction in Charter Schools. Education Reform Faculty and Graduate Students Publications. Retrieved from https://scholarworks.uark.edu/edrepub/14

This Article is brought to you for free and open access by the Education Reform at ScholarWorks@UARK. It has been accepted for inclusion in Education Reform Faculty and Graduate Students Publications by an authorized administrator of ScholarWorks@UARK. For more information, please contact scholar@uark.edu. 


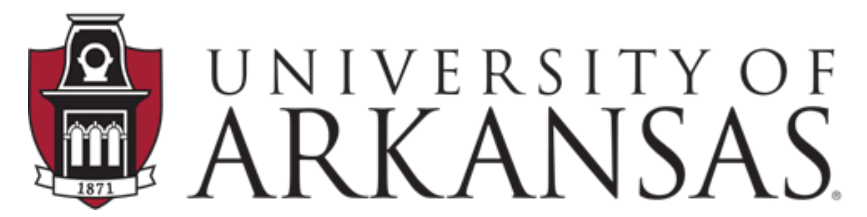

College of Education \& Health Professions Education Reform

\title{
WORKING PAPER SERIES
}

\section{Does Choice Matter for School Choice? An Instrumental Variables Analysis of the Effect of Choice on Parental Satisfaction in Charter Schools}

\author{
Corey A. DeAngelis
}

February 3, 2017

EDRE Working Paper 2017-06

The University of Arkansas, Department of Education Reform (EDRE) working paper series is intended to widely disseminate and make easily accessible the results of EDRE faculty and students' latest findings. The Working Papers in this series have not undergone peer review or been edited by the University of Arkansas. The working papers are widely available, to encourage discussion and input from the research community before publication in a formal, peer reviewed journal. Unless otherwise indicated, working papers can be cited without permission of the author so long as the source is clearly referred to as an EDRE working paper. 
Does Choice Matter for School Choice? An Instrumental Variables Analysis of the Effect of Choice on Parental Satisfaction in Charter Schools

\author{
Corey A. DeAngelis \\ Department of Education Reform, \\ University of Arkansas \\ cadeange@uark.edu
}

February 3, 2017

\title{
Acknowledgements
}

The content of the report is solely the responsibility of the author and does not necessarily represent the views of the University of Arkansas. I appreciate the extensive comments on previous drafts from Gary W. Ritter and Malachi Nichols. All remaining flaws are my own. Corresponding author is Corey A. DeAngelis, cadeange@email.uark.edu. 


\begin{abstract}
I employ ordered probit regression, and a new instrumental variable, to compare the fall 2015 parental satisfaction survey results of open-enrollment charters to district-conversion charters.

The results indicate that choice status in Arkansas charter schools is significantly beneficial to parental-satisfaction. In particular, after controlling for student and parent-level characteristics, parents with children in open-enrollment charters had between a 17-percentage point and 32-percentage point higher likelihood of grading their current school as an $A$ or responding as Highly Satisfied in six of the quality categories: Overall, Teacher, Discipline, Learning, Safety and Parental-Involvement. Four of the relationships remain large and statistically-significant in the instrumental variables analysis. I find no evidence that parents in either choice setting rate the quality of schools similar to the experts at the Arkansas Department of Education. Finally, I do not find any significant differences for any of the parentalsatisfaction categories between oversubscribed and non-oversubscribed schools.
\end{abstract}

Keywords: school choice; charter school; oversubscription; instrumental variables 


\section{Background}

There have been hundreds of school choice evaluations across the globe. Most evaluations have focused on test scores (CREDO, 2013; Zimmer et al., 2009), but others have examined alternative outcomes such as safety and parental satisfaction (Kisida \& Wolf, 2015; Witte, 2001. Meta analyses have concluded that, on average, school choice programs have a small positive impact on student achievement (Betts \& Tang, 2011; Shakeel, Anderson \& Wolf, 2016); however, impacts are largest for charters in urban areas and private schools outside of the United States. Additionally, studies have found that school choice programs could increase graduation rates (Cowen et al., 2013; Wolf et al., 2013), decrease criminal activity (DeAngelis \& Wolf, 2016; Deming, 2011; Dills \& Hernandez-Julian, 2011), and decrease teen pregnancy (Dobbie \& Fryer, 2015). Nonetheless, few studies have endeavored to explain the specific mechanisms that lead to these academic outcomes.

Wolf and Hoople (2006) attempted to peer into the black box of private school choice by examining the characteristics of schools that were improving the achievement of voucher students participating in the DC Opportunity Scholarship Program. They found that successful participating private schools allocated fewer resources to elaborate schooling facilities and programs. They also found that responsible teachers, advantaged peer-groups and timeconsuming homework assignments might increase student achievement for voucher beneficiaries.

Additionally, Figlio and Hart (2010) and Anna Egalite (2013) conducted reviews of the evidence on the competitive effects of school choice programs on residentially-assigned public schools; both studies found clear positive impacts on the local public schools through an 
increased competitive environment. However, none of these studies have empirically examined the impact of choice itself on school quality as measured by parental satisfaction.

\section{Charter Schools in Arkansas}

In 1995, charter schools were approved in Arkansas under the passage of Act 1126, allowing only for district-conversion charters. District-conversion charters are public schools that have been converted into charter schools that can only pull students from within district lines. Without the freedom often associated with becoming a charter school, the state received no charter applications, which required the issue to be revisited in 1999 (Mills, 2013). Act 890 passed in 1999, allowing for open-enrollment charters, which are charters managed by either a governmental entity, institution of higher education, or a tax-exempt non-sectarian organization that can draw students beyond district lines. Two years after the passage of Act 890, the state's first four charter schools opened.

Arkansas continues to operate under the district-conversion and open-enrollment charter models today. In 2016, there are 28 district-conversion charters and 24 open-enrollment charters within the state. ${ }^{1}$

The charter school sector in Arkansas gives us a unique opportunity to examine the potential effect of schooling choices on parental satisfaction, especially since conversion charters are simply alterations of existing schools in traditional districts. In other words, while districtconversion schools may be labeled as charters, open-enrollment schools actually allow families to exercise a higher degree of choice. Since parents do not have many alternatives to the districtconversion charter schools, I attempt to examine the impact that choice ${ }^{2}$ may have on parental

\footnotetext{
${ }^{1}$ http://www.arkansased.gov/

${ }^{2}$ Obviously, choice is not the only difference between district-conversion and open-enrollment charters, so it is impossible to determine if we are indeed measuring the impact of choice itself.
} 
satisfaction. In order to do so, I use data from a survey administered to parents of children enrolled in charter schools throughout the state of Arkansas during the fall of 2015. Specifically, I observe the differences between the survey responses of parents in open-enrollment (highchoice) and parents in district-conversion (low-choice) charter schools.

\section{Theory}

\section{Choice and Parental Satisfaction}

While a different leadership body may be important to the success of charter schools, theory indicates that parental school choice may be paramount. If a family can choose the school for their child, there may be large benefits tied to the improved match between student interests and school mission. Additionally, schools of choice experience amplified competitive pressures to increase quality since their students are able to exit. Parents of children in choice schools may be more satisfied since these schools have an increased incentive to cater to the needs of the families. These theoretical explanations lead us to believe that the parental school choice aspect of charter schools in Arkansas will have a positive impact on school quality as measured by parent responses to a survey administered in the fall of 2015.

\section{Choice and Information}

In addition, I hypothesize that parents with children in a stronger choice setting will be more informed about the quality levels of their different schooling options. If a family enjoys real power to choose the educational environment for their children, they may have an increased incentive to seek out information about school quality. On the other hand, if a family does not have a strong set of alternative schooling choices, they may not have a powerful incentive to seek out quality differentials. However, the families that do not enjoy a strong exit option may understand that they must voice their opinions in the public realm in order to push for schooling 
improvements. Furthermore, if a parent only has to research one or two schooling options, they may be more informed about those two options than parents that seek information on several additional schooling options. If this is the case, the parents without a powerful exit option may have an even greater incentive to seek out information in order to strengthen their remaining voice option. I test these two competing theories by examining the power of the local school grade given by parents in two different choice settings to predict the grade assigned to the same school by the Arkansas Department of Education (DoED). ${ }^{3}$

\section{High-Demand Charter Schools and Parental Satisfaction}

Lastly, I hypothesize that parents with children that were lucky enough to win a seat in oversubscribed schools will be more satisfied relative to parents with children that are in schools with excess capacity. Economists point out that a school with a waitlist experiences a shortage because the quantity of seats demanded by families exceeds the quantity supplied by schooling producers. This excess demand is typically an indicator that the consumer of the product perceives that its quality exceeds the other available options. However, economists also argue that the same shortage condition leads to diminishing quality within schools because the school operators do not have as much as an incentive to improve quality since it has more customers than it needs. If a parent is not satisfied with an oversubscribed school, they can exit without much pain inflicted upon the school operators since another willing, happy customer will quickly replace the unhappy one. I assess these two competing theories by examining the satisfaction levels for parents with children in oversubscribed schools compared to those in schools with excess capacity.

\footnotetext{
${ }^{3}$ http://www.officeforeducationpolicy.org/arkansas-schools-data-letter-grades/
} 
To summarize, the three research questions of interest are:

1. Do open-enrollment (choice) schools increase parental satisfaction?

2. Do open-enrollment (choice) schools increase parents' abilities to rate school quality?

3. Does having a child in an oversubscribed (high-demand) school increase satisfaction?

\section{Data and Methods}

I use data from a survey administered to parents of students in Arkansas charter schools in the fall of 2015. The survey used paper-and-pencil and electronic formats, and was provided to all open-enrollment and district-conversion charter school leaders with a request to share the survey with all parents at the school and to make sure respondents remained anonymous. I have a final sample size of 2,597 parents; 2,234 (86\%) are in open-enrollment schools while only 363 (14\%) are in district-conversion schools. A limitation of the analysis is that the overall sample response rate is only 11 percent. On average, parents with children in middle schools and openenrollment charters were more likely to respond to the survey.

Perhaps most problematic is the difference in response rates between open-enrollment and district-conversion charter parents. Specifically, open-enrollment parents had an $18.15 \%$ response rate, while the response rate for district-conversion parents was $3.50 \%$. This makes the analysis especially prone to survey-selection bias, however, it is not clear which direction the bias should be. This could make the results more or less favorable for open-enrollment parents based on the type of parents that selected into the survey.

I find that the survey respondents may be a more advantaged group than their schools overall, especially for district-conversion charters. ${ }^{4}$ The respondents from district-conversion

\footnotetext{
${ }^{4}$ Weighting each observation by the inverse probability of response does not change the signs of the overall results, but coefficients attenuate towards zero and standard errors rise. Specifically, only one result from the main analysis remains statistically significant, while four become marginally significant at the $p<0.10$ level. These results can be found in the Appendix.
} 
charter schools were less likely to have children that were special needs, free-or-reduced lunch eligible, or a minority race than their school overall. The respondents from open-enrollment charter schools were less likely to have children that were Hispanic or free-or-reduced lunch eligible than their school overall. However, open-enrollment respondents were less likely to be white and more likely to have special needs. Because of these differences, the responses could result in upward bias on scores from parents of children within district-conversion charter schools. This could explain why weighting by response rate diminishes the effects overall.

Since the survey responses related to parental satisfaction are ordinal, the analytic technique I employ is an ordered probit regression of the form:

$$
\text { Satisfaction }_{i}=\boldsymbol{\beta}_{0}+\boldsymbol{\beta}_{1} \text { Choice }_{i}+\boldsymbol{\beta}_{2} X_{i}+\boldsymbol{\beta}_{3} Z_{i}+\varepsilon_{i}
$$

However, since the open-enrollment status of a given school, $i$, may remain to be endogenous, I also employ an instrumental variables ordered probit approach of the form:

$$
\begin{aligned}
& \text { Satisfaction }_{i}=\boldsymbol{\beta}_{0}+\boldsymbol{\beta}_{1} \text { Choice }_{i}+\boldsymbol{\beta}_{2} X_{i}+\boldsymbol{\beta}_{3} Z_{i}+\varepsilon_{i} \\
& \text { Choice }_{i}=\boldsymbol{\beta}_{0}+\Omega_{1} \text { Commute }_{i}+\boldsymbol{\beta}_{2} X_{i}+\boldsymbol{\beta}_{3} Z_{i}+\varepsilon_{i}
\end{aligned}
$$

Additionally, I conduct an ordinary least squares regression analysis where I examine how a second explanatory variable of interest predicts school grades given by researchers:

$$
\text { DoEDGrade }_{i}=\boldsymbol{\beta}_{0}+\lambda_{1} \text { LocalSchoolsParentGrade }_{i}+\boldsymbol{\beta}_{2} X_{i}+\boldsymbol{\beta}_{3} Z_{i}+\varepsilon_{i}
$$

Finally, I conduct an ordered probit regression analysis where I examine a third explanatory variable of interest:

$$
\text { Satisfaction }_{i}=\boldsymbol{\beta}_{0}+\alpha_{1} \text { Oversubscribed }+\boldsymbol{\beta}_{2} X_{i}+\boldsymbol{\beta}_{3} Z_{i}+\varepsilon_{i}
$$

Where Satisfaction is the outcome variable of interest. This variable captures nine different aspects of school quality measured by the parental satisfaction level reported by the parent of child $i$. I examine grades for the school overall, teachers, principals, and facilities. Also, I 
examine satisfaction levels for discipline, extracurricular activities, child learning, safety, and parental involvement. Additionally, I include DoEDGrade as an outcome variable of interest that is the grade given to the residentially-assigned school of parent $i$ as determined by the Arkansas DoED.

The explanatory variable of interest, Choice, captures whether or not a given parent, $i$, has a child enrolled in a charter school that allows families to freely choose an alternative public schooling option. The coefficient of interest, $\lambda_{l}$, attempts to capture the impact that choice has on parental satisfaction. I expect this coefficient to be positive since enhanced choice can provides an incentive for schools to cater to the needs of the families. Since I expect that the choice status of a given school is endogenous, I also employ a two-stage least squares analytical technique using Commute as an instrument. Commute is the reported commute time between home and the residentially-assigned public school for parent $i$. This instrument should be sufficiently negatively correlated with choice status, especially since open-enrollment charter schools are more likely to locate in densely-populated areas, while district-conversion charter schools are more likely to locate in suburban areas and districts that are geographically spread out. The instrument is redundant since the commute time to the traditional public school does not directly impact the parental satisfaction score for their current charter school. The instrument is exogenous since it is not correlated with any omitted variables that affect parental satisfaction. Importantly, the models all include a control for the commute time to the child's current charter school.

The second explanatory variable of interest, LocalSchoolsParentGrade, is the grade of the residentially-assigned schools as determined by parent $i$. The coefficient of interest, $\boldsymbol{\beta}_{l}$, attempts to capture the power of parents' grades of their residentially-assigned schools to predict 
the scores assigned by the state. I expect this coefficient to be positive overall since enhanced choice can provide an incentive for parents to seek out information about school quality. However, this coefficient could be insignificant if parents feel obligated to seek out an abundance of information on different schooling options, or even negative if parents' values differ from those deemed important by the state.

The last explanatory variable of interest, Oversubscribed, takes on the value of one if the parent has a child in an oversubscribed school, and zero otherwise. In this analysis, the coefficient of interest, $\alpha_{1}$, attempts to capture the impact that being in an oversubscribed school has on parental satisfaction. I expect this coefficient to be positive since getting into a highlydemanded institution can raise parental satisfaction. Alternatively, this coefficient could be insignificantly different from zero if these schools hold a sufficient amount of monopoly power over families; if a school already has more customers than it can serve, it need not be as worried about the wishes of its current customers.

I also include vector $X$ of student-level controls such as grade, years at current institution, number of siblings at school, commute time to school, free or reduced lunch (FRL) status, and special education (SPED) status. Additionally, I include vector $Z$ of parent-level controls such as race, education level, employment status, relationship to student, number of children in school, the time they spent researching schooling options and the baseline measure of interest: the overall grade parents assigned to their child's residentially-assigned local schools. The final term, $\mathcal{E}$, is the random error. Since children in the same schools are similar on unobservables, I use robust standard errors clustered at the school-level. 


\section{Descriptive Statistics}

Based on surveys given to parents and guardians, Table 1 shows descriptive statistics of the students in Arkansas charter schools in the fall of 2015. Overall, it appears that students in open-enrollment charter schools are less-advantaged than the students in district-conversion

charter schools. In particular, students are significantly more likely to be a minority race and less satisfied overall with their residentially-assigned school. Additionally, students in openenrollment charter schools are more likely to qualify for the federal lunch program and be identified as requiring special education. Furthermore, over four percent of open-enrollment students have unemployed parents, while less than one percent of district-conversion students have unemployed parents. However, students in open-enrollment schools are more likely to have parents with a college degree. This could be due to labor-market-specific differences across different geographic areas. Since students in open-enrollment charters appear to be lessadvantaged overall, I expect that these schools will have more difficulty providing an adequate education. As a result, their parents may be less satisfied with their schools. 
Table 1: Descriptive Statistics of Students in Arkansas Charter Schools by Choice Status

\begin{tabular}{|l|l|l|}
\hline Variable & Open Enrollment & District Conversion \\
\hline Parent Grade of Local Schools & 2.137 & $2.694^{* * *}$ \\
\hline Oversubscribed School & $0.516^{* * *}$ & 0.006 \\
\hline Grade Level of Student & 6.658 & $9.256^{* * *}$ \\
\hline More than One Child in School & $0.188^{* * *}$ & 0.113 \\
\hline Years at School & 2.743 & $4.338^{* * *}$ \\
\hline White Parents & 0.524 & 0.573 \\
\hline Black Parents & $0.289^{* * *}$ & 0.096 \\
\hline Hispanic Parents & $0.068^{* * *}$ & 0.019 \\
\hline College Degree & $0.544^{* *}$ & 0.457 \\
\hline Unemployed & $0.043^{* *}$ & 0.008 \\
\hline FRL & $0.326^{* * *}$ & 0.237 \\
\hline SPED & $0.119^{*}$ & 0.077 \\
\hline N & 2234 & 363 \\
\hline Note: p $0.05, * *$ & \\
\hline
\end{tabular}

Note: $* \mathrm{p}<0.05, * * \mathrm{p}<0.01, * * * \mathrm{p}<0.001$

The descriptive results from Table 2 below show a seemingly counterintuitive result:

schools with less-advantaged students receive higher grades from parents overall. In particular, parents with students in open-enrollment charters grade their schools around a 3.37 on a 4.0 scale, or a B plus. On the other hand, parents with students in a district-conversion charter grade their schools a high $\mathrm{C}$, on average. Open-enrollment parents also grade their children's teachers and principals higher. There are two possible explanations for these results: the element of choice in charter schools improves student learning, or that disadvantaged parents have a lower 
standard for academic quality. In order to determine which explanation is valid, I control for all observable characteristics in each of the ordered probit models.

Conversely, district-conversion parents grade the facilities of their children's schools higher, on average. This is likely due to the fact that district-conversion charter schools were previously public schools with large facilities and extracurricular programs. The openenrollment charter schools likely did not allocate resources towards those facilities.

Table 2: Arkansas Charter School Grades by Choice Status

\begin{tabular}{|l|l|l|}
\hline School Grade Type & Open Enrollment & District Conversion \\
\hline Overall & $3.367 * * *$ & 2.955 \\
\hline Current Teacher & $3.414 * * *$ & 3.197 \\
\hline Current Principal & $3.267 * *$ & 3.064 \\
\hline Current Facilities & 2.958 & $3.119 * *$ \\
\hline $\mathrm{N}$ & 2234 & 363 \\
\hline Note: $* \mathrm{p}<0.05, * * \mathrm{p}<0.01, * * * \mathrm{p}<0.001$
\end{tabular}

Table 3 shows results based on overall parent satisfaction. The scores on this part of the survey range from one to four, or from "very dissatisfied" to "very satisfied." Again, choice charter schools outperform non-choice charters in each category except for extracurricular activities. In particular, parents with students in open-enrollment charters rate their schools significantly higher in student learning, safety, discipline and parental involvement. In order to understand if choice is what is driving these results, I control for parent and student characteristics in the ordered probit models below. 
Table 3: Arkansas Charter School Parent Satisfaction by Choice Status

\begin{tabular}{|l|l|l|}
\hline Parent Satisfaction Type & Open Enrollment & District Conversion \\
\hline Learning & $3.537 * * *$ & 3.047 \\
\hline Safety & $3.450 * * *$ & 3.201 \\
\hline Discipline & $3.308 * * *$ & 2.964 \\
\hline Parental Involvement & $3.468 * * *$ & 3.051 \\
\hline Extracurricular & 3.000 & $3.111 *$ \\
\hline N & 2234 & 363 \\
\hline Note: $* \mathrm{P}<0.05, * * \mathrm{P}<0.01, * * * \mathrm{P}<0.001$ &
\end{tabular}

\section{Results}

\section{Choice Status - Ordered Probit}

First, I present results for the ordered probit analysis examining the effect of having a child in an open-enrollment charter school on nine different parental satisfaction measures. The coefficient on each variable represents average marginal effects and the coefficient of interest is on "Choice Charter" in each table below.

The results for the effect of being in an open-enrollment charter on the four school grades mirror those reported in Table 2, however, they become statistically insignificant for principals and facilities. Table 4 below illustrates the findings from the ordered probit regression with all student and parent-level controls included. Parents with children in a choice charter have a 23 percentage point higher likelihood of rating their child's school an $A$ overall and a 17 percentage point higher likelihood of rating their child's teacher an $A$. Considering that the incidence rates of parents ranking their child's school as an A were 54\% overall and 59\% for teachers, these effects are quite large. 
Where significance arises, control variables behave as expected. A one letter-grade increase in local school grade is associated with a higher likelihood of grading the current charter school an A. Perhaps children in high-quality residentially-assigned schools move to higherquality charter schools. It is also likely that parents that score local schools higher simply score charter schools higher just because they have a lower bar when it comes to school quality.

Parents with multiple children in the school system are more satisfied, perhaps because they have more political power and interest within their schools. Alternatively, this could simply be that parents place multiple children within schools that they like. However, the more children that a parent has enrolled in the school of interest in the survey, the less satisfied the parent is. This may seem counterintuitive at first, but it could be that parents with many children within a school feel like they have less power to exercise the exit option due to the transaction costs of switching schools. The longer a child has been in a school, the less satisfied parents appear to be. While this also may seem counterintuitive, it could be that parents with children in a school for a long period of time find out more things to become frustrated with and feel less power to exercise the exit option due to sunk costs. Unsurprisingly, parents with children that are able to attend their first choice school were much more likely to rate their schools an A.

It appears that the school system overall is performing the lowest for African American families. In three out of four categories, African American parents had around a 16 percentage point lower likelihood of rating their child's charter school as an A, all else equal. 
Table 4: The Effect of Choice Status on Parent-Reported School Grade

\begin{tabular}{|c|c|c|c|c|}
\hline & Overall & Teacher & Principal & Facilities \\
\hline Choice Charter & $\begin{array}{l}\mathbf{0 . 2 3 4} * * * \\
(\mathbf{0 . 0 0 1 )}\end{array}$ & $\begin{array}{l}\mathbf{0 . 1 7 0} * * \\
(\mathbf{0 . 0 0 5})\end{array}$ & $\begin{array}{l}0.118 \\
(0.173)\end{array}$ & $\begin{array}{l}-0.121 \\
(0.107)\end{array}$ \\
\hline Local School Grade & $\begin{array}{l}0.065 * * \\
(0.007)\end{array}$ & $\begin{array}{l}0.056^{*} \\
(0.045)\end{array}$ & $\begin{array}{l}0.028 \\
(0.232)\end{array}$ & $\begin{array}{l}0.025 \\
(0.352)\end{array}$ \\
\hline Student Grade & $\begin{array}{l}0.010 \\
(0.086)\end{array}$ & $\begin{array}{l}0.000 \\
(0.951)\end{array}$ & $\begin{array}{l}0.009 \\
(0.150)\end{array}$ & $\begin{array}{l}0.005 \\
(0.348)\end{array}$ \\
\hline Multiple Children & $\begin{array}{l}0.074 \\
(0.056)\end{array}$ & $\begin{array}{l}0.064 \\
(0.070)\end{array}$ & $\begin{array}{l}0.023 \\
(0.588)\end{array}$ & $\begin{array}{l}0.001 \\
(0.986)\end{array}$ \\
\hline Years at School & $\begin{array}{l}-0.012 \\
(0.058)\end{array}$ & $\begin{array}{l}-0.008 \\
(0.205)\end{array}$ & $\begin{array}{l}-0.018^{*} \\
(0.027)\end{array}$ & $\begin{array}{c}-0.017 * \\
(0.032)\end{array}$ \\
\hline Mother & $\begin{array}{l}0.008 \\
(0.772)\end{array}$ & $\begin{array}{l}0.020 \\
(0.570)\end{array}$ & $\begin{array}{l}0.009 \\
(0.798)\end{array}$ & $\begin{array}{l}0.006 \\
(0.702)\end{array}$ \\
\hline Children Enrolled & $\begin{array}{l}-0.038 * \\
(0.020)\end{array}$ & $\begin{array}{l}-0.050^{* * *} \\
(0.001)\end{array}$ & $\begin{array}{l}-0.048 * * * \\
(0.001)\end{array}$ & $\begin{array}{l}-0.013 \\
(0.438)\end{array}$ \\
\hline Commute Time & $\begin{array}{l}-0.024 \\
(0.127)\end{array}$ & $\begin{array}{l}-0.034 * * \\
(0.008)\end{array}$ & $\begin{array}{l}-0.034^{*} \\
(0.021)\end{array}$ & $\begin{array}{l}-0.015 \\
(0.241)\end{array}$ \\
\hline First Choice School & $\begin{array}{l}0.245 * * * \\
(0.000)\end{array}$ & $\begin{array}{l}0.182 * * * \\
(0.000)\end{array}$ & $\begin{array}{l}0.205 * * * \\
(0.000)\end{array}$ & $\begin{array}{l}0.188 * * * \\
(0.000)\end{array}$ \\
\hline Private Contacted & $\begin{array}{l}-0.038 \\
(0.150)\end{array}$ & $\begin{array}{l}-0.001 \\
(0.955)\end{array}$ & $\begin{array}{l}-0.023 \\
(0.473)\end{array}$ & $\begin{array}{l}-0.026 \\
(0.349)\end{array}$ \\
\hline Private Visited & $\begin{array}{l}0.052 \\
(0.087)\end{array}$ & $\begin{array}{l}0.010 \\
(0.736)\end{array}$ & $\begin{array}{l}0.023 \\
(0.443)\end{array}$ & $\begin{array}{l}0.044 \\
(0.103)\end{array}$ \\
\hline Black & $\begin{array}{l}-0.153 * * * \\
(0.000)\end{array}$ & $\begin{array}{l}-0.163 * * \\
(0.005)\end{array}$ & $\begin{array}{l}-0.168 * * \\
(0.002)\end{array}$ & $\begin{array}{l}-0.019 \\
(0.765)\end{array}$ \\
\hline Asian & $\begin{array}{l}0.026 \\
(0.699)\end{array}$ & $\begin{array}{l}-0.032 \\
(0.509)\end{array}$ & $\begin{array}{l}-0.008 \\
(0.885)\end{array}$ & $\begin{array}{l}-0.039 \\
(0.317)\end{array}$ \\
\hline Hispanic & $\begin{array}{l}0.081 \\
(0.290)\end{array}$ & $\begin{array}{l}0.097 \\
(0.167)\end{array}$ & $\begin{array}{l}0.058 \\
(0.383)\end{array}$ & $\begin{array}{l}0.014 \\
(0.823)\end{array}$ \\
\hline Education Level & $\begin{array}{l}0.039 \\
(0.052)\end{array}$ & $\begin{array}{l}0.039 \\
(0.128)\end{array}$ & $\begin{array}{l}0.018 \\
(0.333)\end{array}$ & $\begin{array}{l}-0.022 \\
(0.381)\end{array}$ \\
\hline FRL & $\begin{array}{l}-0.083 \\
(0.079)\end{array}$ & $\begin{array}{l}-0.072 \\
(0.122)\end{array}$ & $\begin{array}{l}0.037 \\
(0.576)\end{array}$ & $\begin{array}{l}-0.000 \\
(0.999)\end{array}$ \\
\hline Work Status & $\begin{array}{l}0.006 \\
(0.491)\end{array}$ & $\begin{array}{l}0.019 * * \\
(0.004)\end{array}$ & $\begin{array}{l}-0.008 \\
(0.407)\end{array}$ & $\begin{array}{l}0.002 \\
(0.854)\end{array}$ \\
\hline SPED & $\begin{array}{l}-0.039 \\
(0.226)\end{array}$ & $\begin{array}{l}-0.011 \\
(0.801)\end{array}$ & $\begin{array}{l}0.043 \\
(0.218)\end{array}$ & $\begin{array}{l}0.052 \\
(0.065)\end{array}$ \\
\hline Pseudo $\mathrm{R}^{2}$ & 0.0973 & 0.0802 & 0.0495 & 0.0291 \\
\hline $\mathrm{N}$ & 1458 & 1456 & 1441 & 1459 \\
\hline
\end{tabular}

Notes: p-values in parentheses. Standard errors clustered at the school level. All coefficients are average marginal effects for the highest outcome category. $* p<0.05$, ** $p<0.01$, *** $p<0.001$ 
The results for the effect of being in an open-enrollment charter on the five school satisfaction categories mirror those reported in Table 3, however, they become only marginally significant for extracurricular activities. Table 5 below shows a similar story as before: after controlling for background characteristics, open-enrollment status is associated with higher satisfaction in four out of five categories. Parents that have children in choice charter schools have a 23 percentage point higher likelihood of being highly satisfied with school discipline, a 32 percentage point higher likelihood of being highly satisfied with child learning, a 19 percentage point higher likelihood of being highly satisfied with safety, and a 24 percentage point higher likelihood of being highly satisfied with parental involvement. These effects are also quite large, considering that the incidence rates of the highly satisfied rating were $44 \%$ for discipline, $58 \%$ for child learning, 50\% for safety, and 54\% for parental involvement.

Where significance arises, the control variables act identical to those in Table 4. However, four new findings emerge. First, the more private schools that were contacted by the parents while researching their options, the less satisfied they were with their current school's extracurricular activities. This may be due to the cognitive dissonance created through contacting many other options; if a parent is constantly thinking about the extravagant extracurricular activities advertised and offered by the non-chosen schools, they will be less happy with their choice. Alternatively, the more private schools that were actually visited by the parents, the more satisfied they were with their current school's extracurricular activities. Perhaps seeing these advertised facilities in person helped eliminate cognitive dissonance for these parents.

Secondly, Asian parents were less likely to be satisfied with the school's desire for parental involvement and the learning experienced by their children, all else equal. Perhaps, on 
average, Asian cultures have a higher standard for what quality learning and parental

engagement should look like. Interestingly, parents with more children within a school are more satisfied with safety at school, perhaps because the enhanced network created through siblings can reinforce safety. Lastly, parents with students that are identified as having special needs are less satisfied with child learning and more satisfied with safety, all else equal.

Table 5: The Effect of Choice Status on Parent-Reported School Satisfaction

\begin{tabular}{|c|c|c|c|c|c|}
\hline & Discipline & Extracurr & Learning & Safety & Parental Involve \\
\hline Choice Charter & $\begin{array}{l}0.232 * * * \\
(0.000)\end{array}$ & $\begin{array}{l}-0.076 \\
(0.076)\end{array}$ & $\begin{array}{l}0.321 * * * \\
(\mathbf{0 . 0 0 0 )}\end{array}$ & $\begin{array}{l}\text { 0.188** } \\
(\mathbf{0 . 0 0 2 )}\end{array}$ & $\begin{array}{l}\text { 0.238*** } \\
(\mathbf{0 . 0 0 0 )}\end{array}$ \\
\hline Controls & Yes & Yes & Yes & Yes & Yes \\
\hline Pseudo $\mathrm{R}^{2}$ & 0.0516 & 0.0377 & 0.0676 & 0.0507 & 0.0469 \\
\hline $\mathrm{N}$ & 1456 & 1446 & 1454 & 1454 & 1449 \\
\hline
\end{tabular}

Notes: p-values in parentheses. Standard errors clustered at the school level. All coefficients are average marginal effects for the highest outcome category. ${ }^{*} \mathrm{p}<0.05, * * \mathrm{p}<0.01, * * * \mathrm{p}<0.001$

\section{Choice Status - Instrumental Variables Ordered Probit}

Next, I present results for the ordered probit analysis examining the effect of having a child in an open-enrollment charter school on nine different parental satisfaction measures. The first stage of this analysis predicts the potentially endogenous explanatory variable of interest, open-enrollment charter, with the exogenous instrumental variable, local public school commute time. The coefficient on each variable represents average marginal effects and the coefficient of interest is on " Choice Charter" in each table below.

Overall, results are similar for the instrumental variables analysis, but as expected with this type of approach, standard errors increase. As shown in Table 6 below, all results have the same signs as before, but statistical significance only remains for the facilities grade. Parents with children in open-enrollment charter schools have a 28 percentage point lower likelihood of rating the facilities of their charter school as an A. 
The results in Table 7 are highly comparable to the previous models; statistical significance remains for three of the five parental satisfaction variables: discipline, extracurricular activities, and child learning. In particular, parents with children in openenrollment charter schools have a 27 percentage point higher likelihood of being highly satisfied with school discipline, a 27 percentage point lower likelihood of being highly satisfied with extracurricular activity, and a 42 percentage point higher likelihood of being highly satisfied with child learning, all else equal. Additionally, parents with children in open-enrollment charter schools have a 33 percentage point higher likelihood of being highly satisfied with parental involvement, although this effect is only marginally significant. The only satisfaction variable that becomes completely insignificant is school safety. It is likely that the unobservables from the original model are mostly correlated with safety in schools.

The first stage of the model finds that the child's commute time to the local public school is negatively correlated with open-enrollment status of the charter school, as expected.

Specifically, a ten-minute increase in the commute time to the local public school is associated with a 2.4 percentage point lower likelihood of being in an open-enrollment charter rather than a district-conversion charter, all else equal. The relationship between the instrument and the endogenous explanatory variable of interest is relatively strong and statistically significant at the $\mathrm{p}<0.01$ level. The instrument is redundant since traditional public school commute time does not directly affect the charter school satisfaction level. Additionally, the local public school commute time is not related to any of the nine outcome variables when I include the instrument in the structural model. The instrument is not correlated with any omitted variables that may affect the parental satisfaction level, so it is exogenous. Conveniently, all of the models also include the commute time between home and the current charter school as a control variable. 
Table 6: The Effect of Choice Status on Parent-Reported School Grade

\begin{tabular}{lllll}
\hline & Overall & Teacher & Principal & Facilities \\
\hline Choice Charter & $\begin{array}{l}\mathbf{0 . 1 8 5} \\
\mathbf{( 0 . 2 3 5 )}\end{array}$ & $\begin{array}{l}\mathbf{0 . 2 3 0} \\
\mathbf{( 0 . 1 7 4 )}\end{array}$ & $\begin{array}{l}\mathbf{0 . 0 0 6} \\
\mathbf{( 0 . 9 7 1 )}\end{array}$ & $\begin{array}{l}\mathbf{- 0 . 2 7 7 *} \\
(\mathbf{0 . 0 4 7})\end{array}$ \\
Controls & Yes & Yes & Yes & Yes \\
\hline Pseudo R & 0.0861 & 0.0745 & 0.0475 & 0.0277 \\
\hline $\mathrm{N}$ & 1447 & 1444 & 1429 & 1447 \\
\hline
\end{tabular}

Notes: $\mathrm{p}$-values in parentheses. Standard errors clustered at the school level. All coefficients are average marginal effects for the highest outcome category. ${ }^{*} \mathrm{p}<0.05, * * \mathrm{p}<0.01, * * * \mathrm{p}<0.001$

Table 7: The Effect of Choice Status on Parent-Reported School Satisfaction

\begin{tabular}{|c|c|c|c|c|c|}
\hline & Discipline & Extracurr & Learning & Safety & Parental Involve \\
\hline - Choice Charter & $\begin{array}{l}0.274 * \\
(0.048)\end{array}$ & $\begin{array}{l}-0.272 * \\
(0.045)\end{array}$ & $\begin{array}{l}0.422 * * \\
(0.003)\end{array}$ & $\begin{array}{l}0.008 \\
(0.965)\end{array}$ & $\begin{array}{l}0.327 \\
(0.067)\end{array}$ \\
\hline Controls & Yes & Yes & Yes & Yes & Yes \\
\hline Pseudo $\mathrm{R}^{2}$ & 0.0425 & 0.0392 & 0.0458 & 0.0438 & 0.0371 \\
\hline $\mathrm{N}$ & 1444 & 1434 & 1442 & 1442 & 1437 \\
\hline
\end{tabular}

Notes: p-values in parentheses. Standard errors clustered at the school level. All coefficients are average marginal effects for the highest outcome category. $* \mathrm{p}<0.05, * * \mathrm{p}<0.01, * * * \mathrm{p}<0.001$

\section{Predicting School Quality Scores}

This section presents results for the regression analysis examining the relationship between the grade assigned to the local public school by the state and the grade assigned to the same school by the parent. I also examine which choice environment allows for parents to grade local public schools similar to the analysts at the Arkansas DoED.

Overall, Table 8 indicates that parents with students in charter schools do not rate their local public school similar to government officials in Arkansas. This relationship is essentially zero for the grades assigned to local public schools by parents in both open-enrollment and district-conversion charter schools.

It may be that the parents with children in charter schools have a definition of quality that slightly differs from the state's. Perhaps these parents value the safety of the school above all 
other things, while the state may place the highest weight to the academic achievement of students. Since the values of the state and parents may be misaligned, there are two separate explanations for this. It is either that charter parents value inappropriate things, or that researchers in distant offices aren't completely capturing the quality of schools based on observable measurements.

Table 8: The Predictive Power of Parental Grades by Choice Status

\begin{tabular}{ll}
\hline & DoED Grade \\
\hline Local School Grade & $\mathbf{- 3 . 4 4 0}$ \\
& $\mathbf{( 0 . 1 8 6 )}$ \\
Choice Charter $*$ Local School Grade & $\mathbf{2 . 5 6 2}$ \\
& $\mathbf{( 0 . 5 1 7 )}$ \\
Choice Charter & -16.696 \\
& $(0.397)$ \\
Controls & Yes \\
\hline $\mathrm{R}^{2}$ & 0.1823 \\
\hline $\mathrm{N}$ & 1022 \\
\hline Notes: $\mathrm{p}$-values in parentheses. Standard errors clustered at the school level. All \\
coefficients are average marginal effects. * $\mathrm{p}<0.05, * * \mathrm{p}<0.01, * * * \mathrm{p}<0.001$
\end{tabular}

\section{Oversubscribed Schools}

Finally, I present results for the ordered probit analysis examining the effect of having a child in an open-enrollment charter school on nine different parental satisfaction measures. The coefficient on each variable represents average marginal effects and the coefficient of interest is on "Choice Charter" in each table below.

The results in Tables 9 and 10 may be counterintuitive at first. It appears that being in an oversubscribed school is not significantly related to school quality as measured by parental satisfaction for any of the nine outcome measures. There are a couple of explanations for why the oversubscription status of a school is unrelated to school quality. 
The first explanation is that parents may not know what they want when making schooling decisions for their children, so they pick schools that are at odds with their desires. When children get to the schools that the parents thought were high-quality, they are surprised to find out that the charter school is not as great as they expected. In this case, the presence of excess demand, as measured by waitlists, does not necessarily correlate with quality.

However, I found that most of the oversubscribed schools located near each other, where demand for higher-quality schooling is prominent. In this situation, the supply of charter schooling has not increased enough to support the high level of demand. Since the supply of quality schooling options are limited, the open-enrollment charter schools enjoy a large amount of monopoly power. Since the charter schools in these areas have waitlists, they need not worry about the satisfaction levels of their customers. In fact, if an unhappy parent takes their child out of the institution, the charter school will quickly replace them with a happy parent and be even better off. Consequently, parents in these types of charter schools may be more likely to quietly accept what they are dissatisfied with, on average.

Table 9: The Effect of an Oversubscribed School on Parent-Reported School Grade

\begin{tabular}{lllll}
\hline & Overall & Teacher & Principal & Facilities \\
\hline Oversubscribed & $\mathbf{- 0 . 0 1 9}$ & $\mathbf{- 0 . 0 6 9}$ & $\mathbf{- 0 . 0 2 4}$ & $\mathbf{- 0 . 0 6 8}$ \\
& $\mathbf{( 0 . 8 1 5 )}$ & $\mathbf{( 0 . 4 0 7 )}$ & $\mathbf{( 0 . 7 9 1 )}$ & $\mathbf{( 0 . 3 7 6 )}$ \\
Controls & Yes & Yes & Yes & Yes \\
& & & & \\
\hline Pseudo $\mathrm{R}^{2}$ & 0.0861 & 0.0760 & 0.0478 & 0.0291 \\
\hline $\mathrm{N}$ & 1447 & 1444 & 1429 & 1447 \\
\hline
\end{tabular}

Notes: $\mathrm{p}$-values in parentheses. Standard errors clustered at the school level. All coefficients are average marginal effects for the highest outcome category. ${ }^{*} \mathrm{p}<0.05, * * \mathrm{p}<0.01, * * * \mathrm{p}<0.001$ 
Table 10: The Effect of an Oversubscribed School on Parent-Reported School Satisfaction

\begin{tabular}{llllll}
\hline & Discipline & Extracurr & Learning & Safety & Parental Involve \\
\hline Oversubscribed & $\mathbf{0 . 0 1 3}$ & $\mathbf{- 0 . 0 3 6}$ & $\mathbf{0 . 0 2 7}$ & $\mathbf{0 . 0 1 2}$ & $\mathbf{0 . 0 3 6}$ \\
& $\mathbf{( 0 . 8 0 0 )}$ & $\mathbf{( 0 . 2 2 3 )}$ & $\mathbf{( 0 . 6 2 0 )}$ & $\mathbf{( 0 . 8 0 8 )}$ & $\mathbf{( 0 . 4 2 4 )}$ \\
Controls & Yes & Yes & Yes & Yes & Yes \\
& & & & & \\
\hline Pseudo R & & & & & 0.0517 \\
\hline $\mathrm{N}$ & 0.0410 & 0.0381 & 0.0433 & 0.0354 \\
\hline
\end{tabular}

Notes: p-values in parentheses. Standard errors clustered at the school level. All coefficients are average marginal effects for the highest outcome category. $* \mathrm{p}<0.05, * * \mathrm{p}<0.01, * * * \mathrm{p}<0.001$

\section{Policy Implications}

In summary, I find significant evidence that open-enrollment status increases parent satisfaction levels and has no effect on school rating abilities. I also find that oversubscribed charter schools are not associated with higher or lower satisfaction levels.

The positive association between open-enrollment charter schools and parental satisfaction indicates that the aspect of choice may be important for improving the education system. If the aim is to increase the quality of schools available to children, it would be wise for legislators to approve policies that increase the degree of school choice that is available for families. These policies would include open-enrollment charter schools, vouchers, education savings accounts and tuition tax credits.

The absence of an association between parent satisfaction and scores assigned by the Arkansas DoED suggests that the state should increase access to information on school quality. Additionally, this result suggests that decision-makers ought to be modest regarding their ability to quantify quality in a single metric.

The insignificant relationship between oversubscribed schools and parental satisfaction may be surprising if it is thought of solely as a demand signal. Conversely, it should not surprise us after realizing that it is a signal of parent needs and monopoly power exercised by few 
education suppliers. In order to decrease potentially harmful impacts of monopolies in the education sector, decision-makers should limit these oversubscription situations by decreasing charter school regulations and increasing funding for students in charter schools to match the amount they would receive in a traditional public school.

Although students and parents in open-enrollment schools differ on unobservable characteristics, one may interpret the results from the instrumental variables analysis as causal for these specific groups of students in Arkansas. However, these results should only be applied to charter schools in Arkansas. While there are theoretical reasons to believe that these effects should be similar for other types of parental school choice and locations, readers should not extrapolate these results outside of Arkansas charter schools. Decision-makers should also be cautious in assigning the single aspect of parental choice to these results since open-enrollment charter schools differ from conversion charters in features other than choice. 


\section{References}

Betts, J. R., \& Tang, Y. E. (2011). The effect of charter schools on student achievement: a metaanalysis of the literature. Center on Reinventing Public Education.

Cowen, J. M., Fleming, D. J., Witte, J. F., Wolf, P. J., \& Kisida, B. (2013). School vouchers and student attainment: Evidence from a state-mandated study of Milwaukee's parental choice program. Policy Studies Journal, 41(1), 147-168.

DeAngelis, C. A., \& Wolf, P. J. (2016). The School Choice Voucher: A 'Get Out of Jail' Card?. EDRE Working Paper 2016-03. Available at SSRN: https://ssrn.com/abstract=2743541.

Deming, D. J. (2011). Better schools, less crime?. The Quarterly Journal of Economics, qjr036.

Dills, A. K., \& Hernández-Julián, R. (2011). More choice, less crime. Education Finance \& Policy, 6(2), 246-266.

Dobbie, W., \& Fryer Jr, R. G. (2015). The medium-term impacts of high-achieving charter schools. Journal of Political Economy, 123(5), 985-1037.

Egalite, A. J. (2013). Measuring competitive effects from school voucher programs: a systematic review. Journal of School Choice, 7(4), 443-464.

Figlio, D., \& Hart, C. (2014). Competitive effects of means-tested school vouchers. American Economic Journal: Applied Economics, 6(1), 133-156.

Kisida, B., \& Wolf, P. J. (2015). Customer satisfaction and educational outcomes: Experimental impacts of the market-based delivery of public education. International Public Management Journal, 18(2), 265-285.

Mills, J. N. (2013). The achievement impacts of Arkansas open-enrollment charter schools. Journal of Education Finance, 38(4), 320-342.

Raymond, M. E., Woodworth, J. L., Cremata, E., Davis, D., Dickey, K., Lawyer, K., \& Negassi, Y. (2013). National Charter School Study 2013. Center for Research on Education Outcomes (CREDO), Stanford University.

Shakeel, M., Anderson, K. P., \& Wolf, P. J. (2016). The participant effects of private school vouchers across the globe: a meta-analytic and systematic review. EDRE Working Paper No. 2016-07. Available at SSRN: https://ssrn.com/abstract=2777633

Witte, J. F. (2001). The market approach to education: an analysis of America's first voucher program. Princeton University Press.

Wolf, P. J., \& Hoople, D. S. (2006). Looking inside the black box: what school factors explain voucher gains in Washington, DC? Peabody Journal of Education, 81(1), 7-26. 
Wolf, P. J., Kisida, B., Gutmann, B., Puma, M., Eissa, N., \& Rizzo, L. (2013). School vouchers and student outcomes: Experimental evidence from Washington, DC. Journal of Policy Analysis and Management, 32(2), 246-270.

Zimmer, R., Gill, B., Booker, K., Lavertu, S., Sass, T. R., \& Witte, J. (2009). Charter schools in eight states: Effects on achievement, attainment, integration, and competition (Vol. 869). Rand Corporation. 


\section{Appendix}

\section{Results with Observations Weighted by Response Rates}

\section{Table A1: The Effect of Choice and Being in an Oversubscribed School on Parent-}

Reported School Grade

\begin{tabular}{lllll}
\hline & Overall & Teacher & Principal & Facilities \\
\hline \multirow{2}{*}{ Choice } & 0.135 & 0.098 & 0.024 & -0.083 \\
& $(0.096)$ & $(0.143)$ & $(0.776)$ & $(0.259)$ \\
Oversubscribed & 0.065 & -0.010 & -0.009 & -0.033 \\
& $(0.423)$ & $(0.896)$ & $(0.896)$ & $(0.678)$ \\
\multirow{2}{*}{ Controls } & Yes & Yes & Yes & Yes \\
\hline $\mathrm{N}$ & 1455 & 1453 & 1438 & 1456 \\
\hline
\end{tabular}

Notes: p-values in parentheses. Standard errors clustered at the school level. All coefficients are average marginal effects for the most desirable outcome category. Each parent observation is weighted by inverse of their probability of responding to the survey. $* \mathrm{p}<0.05, * * \mathrm{p}<0.01, * * * \mathrm{p}<0.001$

Table A2: The Effect of Choice and Being in an Oversubscribed School on ParentReported Satisfaction

\begin{tabular}{llllll}
\hline & Discipline & Extracurr & Learning & Safety & $\begin{array}{l}\text { Parent } \\
\text { Involvement }\end{array}$ \\
\hline Choice & 0.127 & -0.119 & $0.190^{*}$ & 0.091 & 0.144 \\
& $(0.067)$ & $(0.050)$ & $(0.012)$ & $(0.260)$ & $(0.060)$ \\
Oversubscribed & 0.054 & $-0.093^{*}$ & $0.100^{*}$ & 0.063 & 0.096 \\
& $(0.257)$ & $(0.031)$ & $(0.040)$ & $(0.208)$ & $(0.056)$ \\
Controls & Yes & Yes & Yes & Yes & Yes \\
\hline $\mathrm{N}$ & 1453 & 1443 & 1451 & 1451 & 1446 \\
\hline
\end{tabular}

Notes: $\mathrm{p}$-values in parentheses. Standard errors clustered at the school level. All coefficients are average marginal effects for the most desirable outcome category. Each parent observation is weighted by inverse of their probability of responding to the survey. $* \mathrm{p}<0.05, * * \mathrm{p}<0.01, * * * \mathrm{p}<0.001$ 
Table A3: Respondents Compared to their Charter Schools Overall

\begin{tabular}{|c|c|c|c|c|}
\hline & $\begin{array}{l}\text { Open- } \\
\text { Enrollment } \\
\text { Sample } \\
\end{array}$ & $\begin{array}{l}\text { Open- } \\
\text { Enrollment } \\
\text { Schools } \\
\end{array}$ & $\begin{array}{l}\text { District- } \\
\text { Conversion } \\
\text { Sample } \\
\end{array}$ & $\begin{array}{l}\text { District- } \\
\text { Conversion } \\
\text { Schools } \\
\end{array}$ \\
\hline Black & $\begin{array}{l}0.289 \\
(0.307)\end{array}$ & $\begin{array}{l}0.284 \\
(0.318)\end{array}$ & $\begin{array}{l}0.092 \\
(0.125)\end{array}$ & $\begin{array}{l}0.290 * * * \\
(0.339)\end{array}$ \\
\hline Hispanic & $\begin{array}{l}0.068 \\
(0.075)\end{array}$ & $\begin{array}{l}0.076 * * * \\
(0.045)\end{array}$ & $\begin{array}{l}0.020 \\
(0.042)\end{array}$ & $\begin{array}{l}0.096 * * * \\
(0.113)\end{array}$ \\
\hline White & $\begin{array}{l}0.523 \\
(0.279)\end{array}$ & $\begin{array}{l}0.561 * * * \\
(0.292)\end{array}$ & $\begin{array}{l}0.576 \\
(0.215)\end{array}$ & $\begin{array}{l}0.586 \\
(0.329)\end{array}$ \\
\hline SPED & $\begin{array}{l}0.118^{* * * *} \\
(0.061)\end{array}$ & $\begin{array}{l}0.067 \\
(0.026)\end{array}$ & $\begin{array}{l}0.078 \\
(0.056)\end{array}$ & $\begin{array}{l}0.099 * * * \\
(0.027)\end{array}$ \\
\hline FRL & $\begin{array}{l}0.326 \\
(0.295)\end{array}$ & $\begin{array}{l}0.444 * * * \\
(0.280)\end{array}$ & $\begin{array}{l}0.238 \\
(0.137)\end{array}$ & $\begin{array}{l}0.615 * * * \\
(0.135)\end{array}$ \\
\hline $\mathrm{N}$ & 2234 & 2234 & 363 & 363 \\
\hline
\end{tabular}

